\title{
NUMERICAL SOULUTION OF FRICTION STIR WELDING USING SYSWELD
}

\section{JANČO Roland ${ }^{1}$, ÉLESZTŐS Pavel $^{2}$, ÉCSI Ladislav ${ }^{3}$}

Slovak University of Technology in Bratislava, Faculty of Mechanical Engineering, Institute of Applied Mechanics and Mechatronics, Nám. slobody 17, 81231 Bratislava, Slovak Republic,

${ }^{1}$ roland.janco@stuba.sk, ${ }^{2}$ pavel.elesztos@stuba.sk, ${ }^{3}$ ladislav.ecsi@stuba.sk

Keywords: Friction stir welding (FSW); aluminum alloy; Finite element method, SYSWELD

Abstract Friction Stir Welding (FSW) is one of the most effective solid state joining processes and has numerous potential applications in many industries. The simulation process can provide the evolution of physicals quantities such as temperature, metallurgical phase proportions, stress and strain, which can be easily measured during welding. The numerical modeling requires the modeling of complex interaction between thermal, metallurgical and mechanical phenomena. The aim of this paper is to describe the thermal-fluid simulation of FSW using the finite element method. In the theoretical part of the paper is heating provided by the by the material flow and contact condition between the tool and the welded material. Thermal-fluid and thermo-mechanical results from numerical simulation using SYSWELD are presented for aluminum alloy.

\section{INTRODUCTION}

Friction stir welding (FSW) is a relatively new joining technology which was developed and patented in 1991 by The Welding Institute (TWI), United Kingdom [1]. This is a solid-state welding process providing good quality of butt and lap joints. The FSW process has been proven to be ideal for creating high quality welds in a number of materials including those which are extremely difficult to weld by conventional fusion welding. A schematic of friction stir welding process is illustrated in Fig. 1.

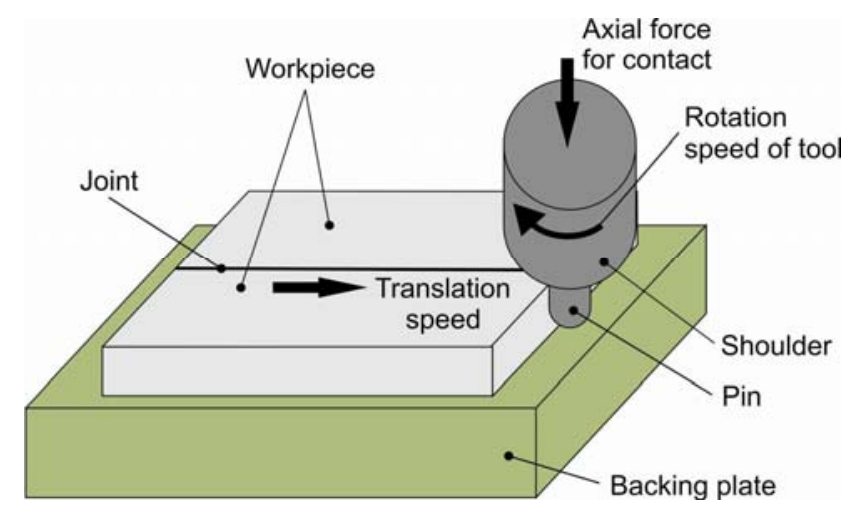

Figure 1: Schematic diagram of FSW.

The welding zone is completely isolated from the atmosphere during the welding process. One of the advantages of this type of welding is minimized formation of voids in the welding 
zone, so that welding defect and large distortion commonly associated with fusion welding are minimized or avoided. This welding technique is extensively applied to the aerospace, automobile and shipbuilding industries $[4,5,6,7,8]$.

\section{THEORETICAL BACKGROUND}

In FSW, the heat generation takes place mainly under the shoulder, leading to variable thermal gradient in the through-thickness direction of the plate. The general three dimensional partial differential equation of heat conduction in solid can be represented by

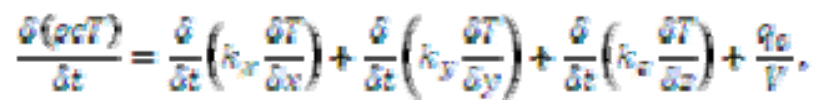

where $\rho c$ is the volume heat capacity; $x, y$ and $z$ are the space coordinates; $k_{x}, k_{y}$ and $k_{z}$ are thermal conductivity, $T$ temperature, $t$ time and $q_{o} / V$.

\subsection{Heat generation during FSW}

For the ideal case considered in Fig.1, the torque required to rotate a circular shaft relative to the plate surface under the action of an axial load is given by [2]

$$
M=\int_{0}^{N r_{K}} d M=\int_{0}^{\pi} 4 P(r) 2 \pi r^{2} d r=\frac{2}{3} \mu \pi R R^{3}
$$

where $M$ is the interfacial torque, $\mu$ is the friction coefficient, $R$ is the surface radius, and $P(r)$ is the pressure distribution across the interface. If all the shearing work at the interface is converted into frictional heat, the average heat input per area and time becomes [2]

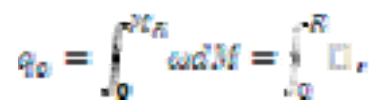

where $q_{o}$ is the net power (in Watts) and $\omega$ is the angular velocity (in $\mathrm{rad} / \mathrm{s}$ ). Angular velocity can by express in term of the rotation speed $N$. By substituting $\omega=2 \pi N$ into Eq. (3), we get

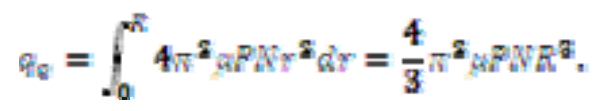

From Eq. (4), it is obvious that the heat input depends both on the applied rotational speed and the shoulder radius, leading to a nonuniform heat generation during welding.

\subsection{Heat generation in SYSWELD by FSW modulus}

In SYSWELD by FSW modulus is effective viscosity $\mu$ defined from Newton-Hoff law used to model hot forming process [3]:

$$
\mu=K(T) \cdot(\sqrt{3}, D)^{m+2}
$$

where $K$ and $m$ are the consistency and the sensibility of material, and $D$ is the equivalent strain rate 


$$
D=\sqrt{\frac{2}{3} \overline{\bar{D}} \overline{\bar{D}_{t}}}
$$

where

$$
\left.\bar{D}=\frac{1}{2}\left(\operatorname{grad}^{2} \bar{y}\right)+\mathrm{grad}^{2}(\bar{v})\right)
$$

The friction between the toll and the work piece is of Neumann boundary condition. Heat flux density modeled between tool and material contact is [3]

$$
q=\beta \cdot \vec{r} \cdot \Delta \overrightarrow{v_{0}}
$$

where $\beta$ is the proportion of the heat dissipated thought viscous dissipation $\vec{\nabla} \Delta \vec{v}$ and received by the sheets. All thermal boundary conditions are in the Fig. 2.

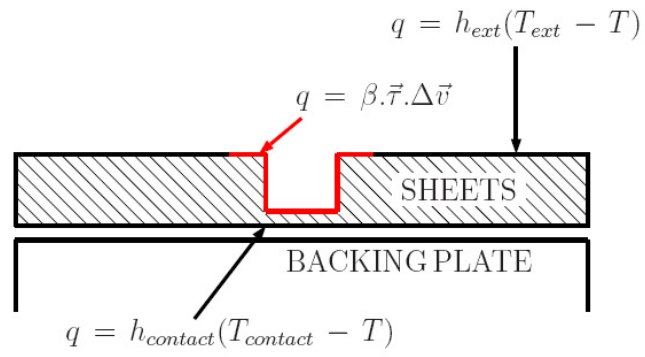

Figure 2: Thermal boundary conditions.

\section{NUMERICAL SOLUTION BY SYSWELD}

An example is presented in this section. The first step of the solution is the thermo-fluid analysis. The thermal properties for the sheet and backing plate are described in Tab. 1, friction coefficient is 0.238 , linear welding velocity is $1.00 \mathrm{~mm} / \mathrm{s}$, tool rotation velocity 41.89 rad.s, room temperature $15^{\circ} \mathrm{C}$, and the heat exchange coefficient for convection $19 \mathrm{~W} /(\mathrm{m} . \mathrm{K})$. In Fig. 3 a finite element model of sheet and backing plate for thermo-fluid analysis is presented. In Fig. 4 a finite element model of the tool is shown. In Fig. 5 a model for thermo-mechanical model and material properties are described in Tab. 1. In fig. 6 and 7 the result of the solution with the SYSWELD ${ }^{\circledR}$ software is presented.

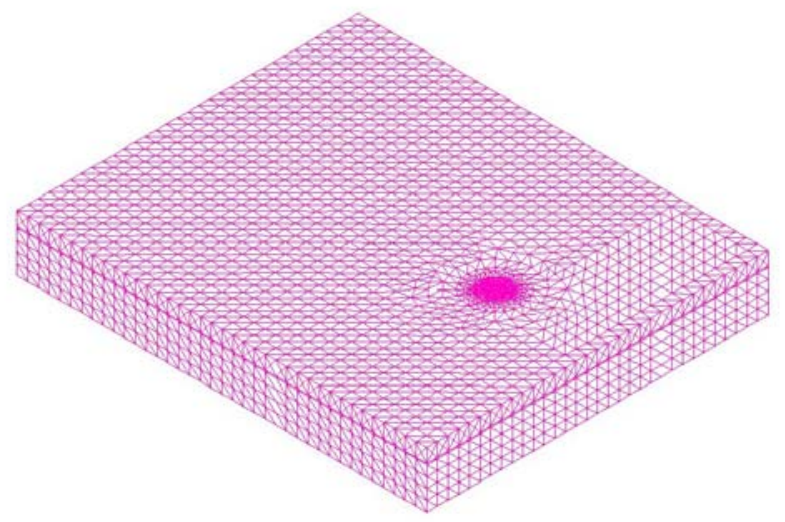

Figure 3: Thermal-fluid model for finite element analysis. 
Figure 4: Finite element model of surface of tool.

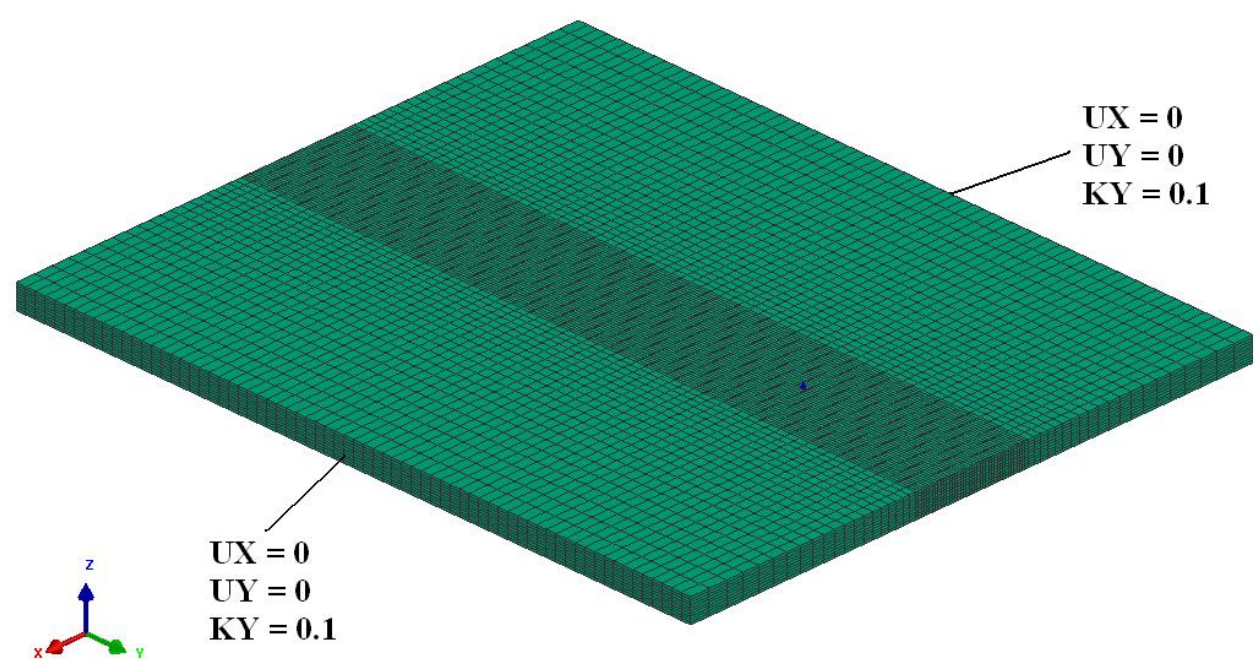

Temperature field is from thermo-fluid analysis.

Figure 5: Thermal-mechanical model with boundary conditions.

Table 1: Material properties of sheet and backing plate.

\begin{tabular}{|c|c|c|c|c|c|c|c|c|c|}
\hline \multirow[b]{2}{*}{$\mathrm{T}\left({ }^{\circ} \mathrm{C}\right)$} & \multicolumn{6}{|c|}{ "SHEET (Aluminum alloy) } & \multicolumn{3}{|c|}{ BACKING PLATE (steel) } \\
\hline & $\frac{k}{W^{*}}$ & $\begin{array}{l}\rho .10^{-6} \\
\left(\frac{\mathrm{kg}}{\mathrm{mm}^{3}}\right)\end{array}$ & $\left(\frac{\mathrm{C}}{\left(\frac{\mathrm{I}}{\mathrm{kg}^{\circ} \mathrm{C}}\right)}\right.$ & $\begin{array}{c}E \\
(\mathrm{GPa})\end{array}$ & $\underset{8}{\eta}$ & $y$ & $\left(\frac{k}{\mathrm{~W}}\right)$ & $\begin{array}{c}\rho .10^{-9} \\
\left(\frac{\mathrm{W}}{\mathrm{mm}^{3}}\right)\end{array}$ & $\begin{array}{c}\mathrm{C} \\
\left(\frac{\mathrm{W}}{\mathrm{kg}^{\circ} \mathrm{C}}\right.\end{array}$ \\
\hline 20 & 0.130 & 2.750 & 898.0 & 70.0 & 0.33 & 0.0125 & 0.068 & 7850 & 430 \\
\hline 120 & & 2.730 & 951.0 & 70.0 & 0.33 & & & & 500 \\
\hline 220 & & 2.710 & 1003.0 & 61.0 & 0.33 & & 0.059 & 7800 & 550 \\
\hline 320 & & 2.690 & 1055.0 & 55.6 & 0.33 & & & & 580 \\
\hline 420 & & 2.660 & 1108.0 & 49.3 & 0.33 & & 0.047 & 7730 & 610 \\
\hline 500 & & & & 41.3 & 0.33 & & & & 650 \\
\hline 587 & 0.170 & 2.630 & 1195.0 & 1.0 & 0.33 & & & & \\
\hline 600 & & & & 1.0 & 0.33 & & 0.036 & 7653 & 710 \\
\hline 644 & & 2.450 & 1200.0 & 1.0 & 0.33 & 0.0135 & & & \\
\hline
\end{tabular}


SCIENTIFIC PROCEEDINGS 2013, Faculty of Mechanical Engineering, STU in Bratislava Vol. 21, 2013, pp. 58-64, DOI: 10.2478/stu-2013-0010

\begin{tabular}{||c||l|l|l|l|l|l||l|l|l||}
\hline 700 & & & & & & & & 7613 & 790 \\
\hline 800 & & & & & & & 0.029 & & 865 \\
\hline 900 & & & & & & & 0.027 & & 565 \\
\hline 1450 & & & & & & & 0.033 & & \\
\hline 1600 & & & & & & & & 7190 & 630 \\
\hline 2477 & & 2.230 & 1300.0 & & & & & & 707 \\
\hline
\end{tabular}

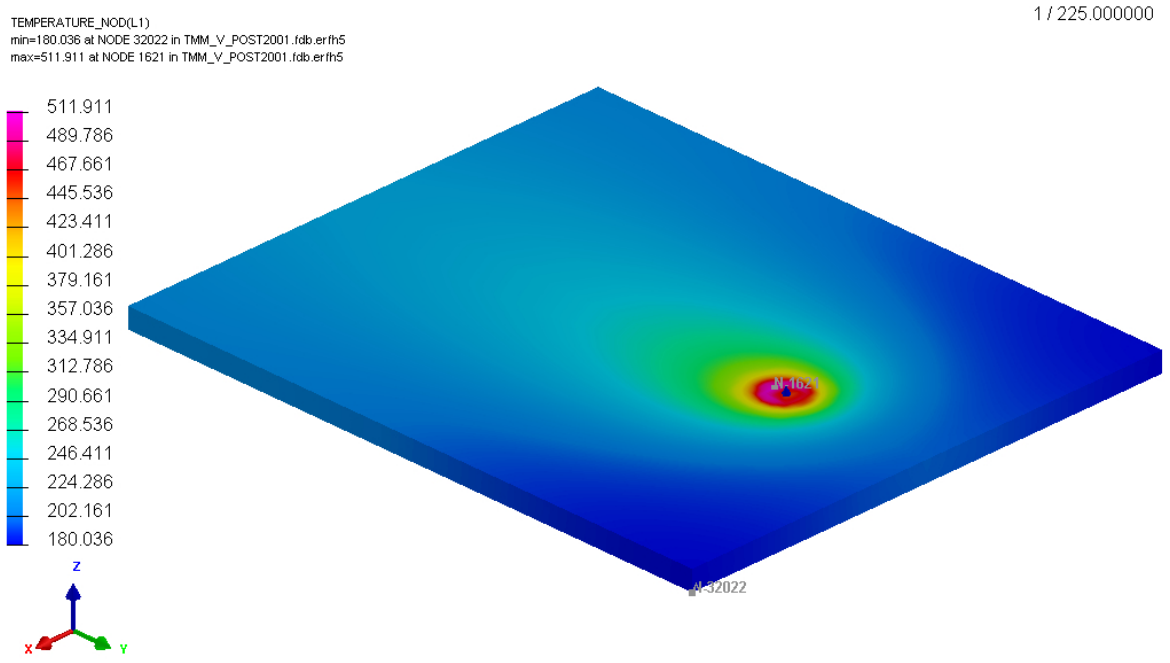

Figure 6: Temperature field at time 225 s of welding. 


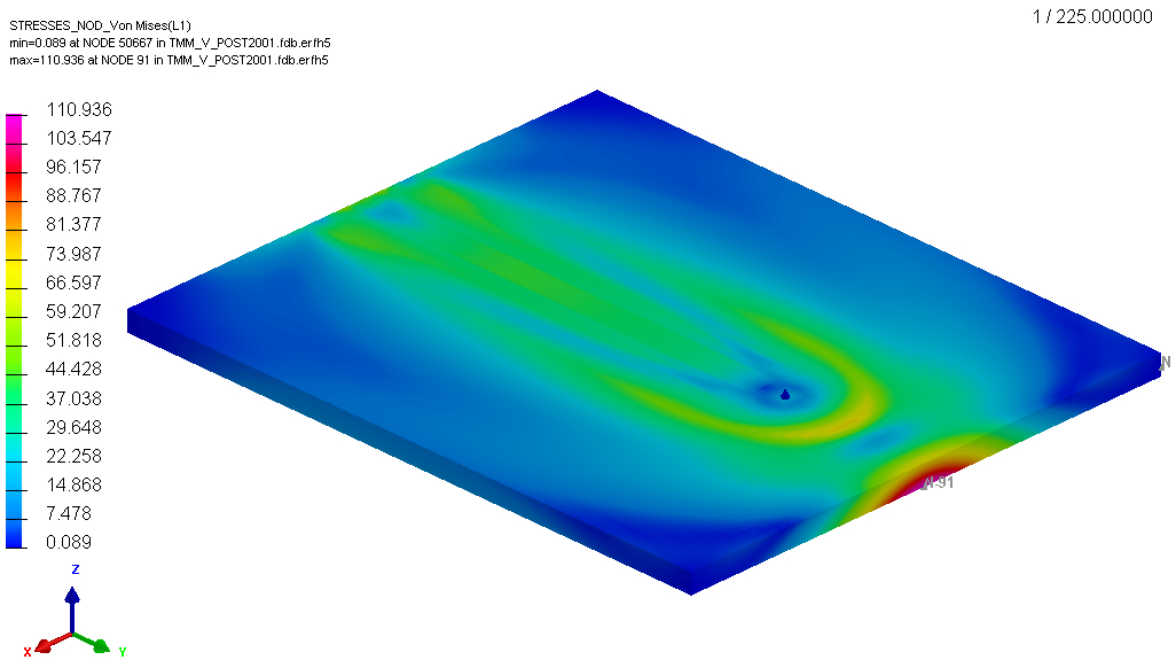

Figure 7: Von Mises stress at time 225 s of welding.

\section{CONCLUSION}

In this paper, 3D finite element procedures are presented to model the thermo-fluid flow and thermo-mechanical properties in FSW for the stationary step in SYSWELD ${ }^{\circ}$. For the computation of the example proposed in section 3, the mesh for thermo-fluid flow analysis is composed of 17892 nodes and 100191 elements in the Fig. 3 and the mesh for thermo-mechanical analysis is composed of 63261 nodes and 56000 elements in the Fig. 5. In Fig. 6 the temperature field at time $225 \mathrm{~s}$ from SYSWELD ${ }^{\circledR}$ is presented. In Fig. 7 the von Mises stress at time $225 \mathrm{~s}$ from SYSWELD ${ }^{\circ}$ is presented. The numerical results were compared to experimental measurements with a thermo-camera, thermocouples and strain rosettes, which are in good agreement [2]. In section 2 a theoretical background is presented for the solution of FSW.

\section{ACKNOWLEDGEMENT}

This publication is the result of the project implementation of: Research of friction stir welding (FSW) application as an alternative to melting welding methods no. 26240220031 supported by the Research \& Development Operational Programme funded by the ERDF. This work was supported by the grant from Grant Agency of APVV no. SK-CZ-0028-11.

\section{REFERENCES}


[1] Chen, C.M., Kovacevic, R.: Finite element modeling of friction stir welding thermal and thermomechanical analysis International Journal of Machine Tools \& Manufacture, Vol. (2003) 43, pp. 1319-1326, ISSN 0890-6955

[2] Frigaard, Ø., Grong, Ø., Midling, O.T.: A Process Model for Friction Stir Welding of Age Hardening Aluminum Alloys Metallurgical and Materials Transactions A, Vol. (2001) 32A, pp. 1189-1200

[3] Feulvarch, E., Robin, V., Boitout, F., Bergheau, J.M.: 3D Modelling of Thermofluid Flow in Friction Stir Welding Including Metallurgical and Mechanical Consequences Mathematical modelling of weld phenomena 8, 2007, pp. 1-24, ISSN 9783902465696

[4] Danko, J., Bugár, M., Staňák, V.: Energy analysis of hybrid power source during vehicle motion In: Scientific Proceedings Faculty of Mechanical Engineering STU Bratislava. ISSN 1338-1954. - ISSN 1338-5011 (ONLINE). - Vol. 19/2011. - , 2011, pp. 37-42

[5] Magdolen, L., Masaryk, M.: Flywheel storage energy. In: Proceedings of the eight international conference on Mechanical Engineering : Gépészet 2012. Budapest, Hungaria, May 24-25, 2012. - Budapest : Budapest Univeristy of Technology and Economics , 2012. - ISBN 978-963-313-055-1. - pp. 296-300

[6] Trebuňa, F., Smrček, J., Bobovský, Z.: The influence of shape for self-reconfigured modular robotic system characteristics. In: Acta Mechanica Slovaka. Roč.14, č. 1 (2010)ISSN 1335-2393

[7] Trebuňa, F.: Príruča experimentálnej mechaniky. Typopress Košice, 2007, ISBN 970-808073-816-7, $1526 \mathrm{~s}$.

[8] Huňady, R. - Trebuňa, F.: Experimentálna analýza kmitania potrubí na výtlaku z plynovodných kompresorov v kompresorovej stanici -2012. In: Slovgas. Roč. 21 č. 2 (2012) s. 17-20. - ISSN 1335-3853 